\title{
E-social Inclusion through B-Learning in the Teaching of the Programming Logic
}

\author{
Iris Jiménez Pitre', Rubén Darío Cárdenas Espinosa ${ }^{2,3 *}$ and Geomar Molina-Bolívar ${ }^{1}$ \\ 'Research Group BIEMARC, University of La Guajira, Riohacha, Colombia; \\ iajimenez@uniguajira.edu.co \\ ${ }^{2}$ Research Group RENUEVATE Ciencia Tecnología e Innovación, University of Caldas; \\ rdcardenas@gmail.com \\ ${ }^{3}$ Research Group GICEMET, Centro Metalmecánico, SENA Distrito Capital, Bogotá, Colombia; \\ rdcardenas75@misena.edu.co
}

\begin{abstract}
Objective: This research is to introduce the use of Information and Communication Technologies ICT as experience in E-social inclusion through the B-Learning in the teaching of the programming logic. Materials and Methods: The methodology corresponds to an experimental research with analytical empirical approach descriptive in nature and cross-section through the Model PACIE (Exposure, Bounce, construction, testing and evaluation) in the training programs of the University of La Guajira, Caldas University, Atlantic International University, and the SENA, carried out in 4 phases: 1. Diagnosis and contextualization. 2. Pilot test in virtual training. 3. Pilot test in classroom training. 4. Transfer and replicability. Finding: The result was the application through hands-on labs mediated by technology in the teaching of the programming logic for troubleshooting. Application: In order to achieve an effective labor insertion is necessary to incorporate in educational processes three approaches: training in emotional intelligence to help remove barriers and prejudices that have people who have been detained in prison, financial intelligence training that allows them to obtain wealth and appropriate management of resources and training technique applied focused on policy formulation, monitoring, implementation and evaluation of projects of technological development and innovation or entrepreneurship to play a craft or trade or with the option Apply to the contests of the government with high odds of winning versus the other.
\end{abstract}

Keywords: Automatisms, B-Learning, E-Inclusion, Logic, TIC en Education

\section{Introduction}

In order to achieve an effective labour insertion is necessary to incorporate in educational processes three approaches: training in emotional intelligence to help remove barriers and prejudices that have people who have been detained in prison, financial intelligence training that allows them to obtain wealth and appropriate management of resources and training technique applied focused on policy formulation, monitoring, implementation and evaluation of projects of technological development and innovation or entrepreneurship to play a craft or trade or with the option apply to the contests of the government with high odds of winning versus the other. Thanks to the application of processes, pilots have made appropriate adjustments to provide an educational process supported by TIC and the Web2.0, with the accompaniment and advice of a working team with experience in various fields of knowledge.

${ }^{*}$ Author for correspondence 
In this project applies the B-Learning in the teaching of the programming logic for the resolution of problems through an electronic design, a computer program or microcontroller, a sequential automatism which are the basis for the development of projects such as the case of those who require the use renewable energy to become self-sustaining; for higher education programs of several universities in which the authors have provided classroom training and/or virtual from the use of different resources Web2.0 as in the case of the implemented through Edublogs (Electrical Circuits, microcontrollers, Draft Grade, PLC), as a product of the Inclusion Doctoral Research Project in Manizales, Colombia Educational Technology through the B-Learning and Information and Communication Technologies (TIC) 1 .

The economic and social reintegration successful labour are key for society as a whole, not only for the population in vulnerable condition does not have to be subjected to exploitation, but also to become active contributors to the economy and receive a second chance for true rehabilitation, and designing didactic methodological strategies active, that will generate a process of educational technology and social inclusion that articulates the B-Learning and Model Presence, Scope, Training , Interaction and patient in E-Learning Technology programs through Information and Communication Technologies 2 .

Currently, the B-Lended Learning is oriented toward a new reconfiguration, a leap inevitable, marked by convergence. This evolution presupposes the synthesis of the pedagogical and technological mediations, making imperceptible the borders that separates them and inadmissible the demarcation of where one ends and the next begins. With the application of ICT in educational processes, the design and implementation of virtual classrooms under various platforms such as Moodle, Blackboard, Neolms, among others; and the ease of various technological processes has led to play the real thing in virtual without making use of any methodology. Thanks to the incorporation of simulators, edublogs, videos and virtual learning objects, they strengthen the competences of trainees with activities of exposure, Bounce, Construction, Testing and
Evaluation. It managed to articulate Web 2.0 resources as a complement to the Blackboard platform through the online sessions of Blackboard Collaborate or Whatsapp, developing the proposed activities and its corresponding weighting ${ }^{3}$.

\section{Materials and Methods}

The research complies with the conditions of a quasi-experimental study, because: it manipulates the independent variable; there is a control group and experimental one, there is no randomness of the sample, nor shall anything be done or control of all the variables involved.

Analytical-empirical Approach: is represented by the development of explanations for the phenomena of reality that are sought to be controlled and/or transformed by man. It is intended that determined the type of experiences that will be particularly productive, could be replicated in relatively new conditions" for this project will be carried out an analysis of the Resources Web 2.0 and the regulations in the area of educational inclusion in higher education programs will be implemented and those that are deemed appropriate to meet the objectives of the project ${ }^{4}$.

Descriptive Character: selects a series of technical factors, technological and engineering that are applicable to the learning needs to represent in combinatorial logic, traditional and combinatorial systems, contacts or similar electronic topics and the selection of the appropriate learning objects that allow students to comply with the results of learning and acquire meaningful learning in line with the objectives of the project. In addition, by the socio-demographic contribution of students that allow you to have a knowledge of your condition and the family history that give explanation of her ${ }^{5}$.

Cross-sectional Study: at the time of information collection is made all at once and immediately proceed to its description or analysis. Within all of the topics in the area of electronics, automation systems, Mechatronics or that are technological programs that are offered at the 
Universities of the city of Manizales. This for the selection of the basic concepts that allow students to acquire the necessary logic to program a PLC, perform a digital electronic design and the programming structure from the boolean logic to enable it to solve a problem and incorporated into the world of work ${ }^{6}$.

Sequences: The project was carried out in three phases: test, design and implementation.

Testing Phase: Once you have analyzed the criteria of operability, functionality, and connectivity in pedagogical practice is important to create a Web 2.0 tool and incorporate it initially in the virtual training courses to assess their feasibility and make adjustments as necessary, on the basis of observations and feedback from trainees, and then incorporate it into the training programs entitled and the community in general.

Design Phase: The design showed how the experimental and control groups will be evaluated with a pre-test to check their learning styles; the experimental group intervened according to the activities with curricular adaptations and the control group with a traditional intervention and subsequently a post-test; as well illustrated by the following expression:

Ya1 X1 Yb1 Experimental group (curricular adaptations)

Ya2 X2 Yb2 Control group (intervention traditional)

After finishing the test phase, is passed to the design phase, checked that comply with the principles Web 2.0, and the selected resources meet the criteria of performance and product knowledge, raised in the competencies in the area of electronics, mechatronics Systems, or Industrial Automation and are consistent with the teaching techniques previously analyzed individually ${ }^{\underline{?}}$.

Implementation Phase: corresponded to the practical component of the implementation of the project, in which the location and distribution of the resources needed according to the technical specifications and technology that meet the Web 2.0 principles of the project, regulations and requirements in the area of work. This project has been carried out in the following stages (stage 0 to 2 were carried out on the basis of Phase 3 and gives the transfer and replicability with other instructors of the Seine and the Universidad de Caldas.:

Phase 0: Diagnosis and Contextualization: an analysis and recognition of the platforms that the Seine and at the University of Caldas has to guide their training processes from the virtual and face-to-face teaching role.

Phase 1: The courses in Digital Electronics from the University of Caldas January 2016 - December 2016: an analysis of Web 2.0 resources that were required and implemented those deemed appropriate to energize the pedagogical practice.

Phase 2: In-Training Programs of the Metallurgical Center Virtual HAUTS-DE-SEINE Capital District February 2017 - June 2017, in 12 tabs for a population of 960 students, 1376133,34,35,36 of implementation of the PLC in 1394755,56,57,58 Automation processes of the PLC on SCADA systems, 1445727,41,42,46 Introduction to Automated Processes.

Phase 3: Transfer and replicability in seedbeds of technological programs and research at the University of Caldas May 2017 - to date, Technological Inclusion of ICT in processes of applied research, technological development and innovation. University of La Guajira.

\section{Results and discussion}

We analyzed the provisions that regulate the processes of educational inclusion in Higher Education programs in Colombia, allowing you to select the Web 2.0 resources that can be adapted to make them inclusive. From the Resources Web 2.0 as Edublog Electrical Circuits, PLC, Edublog Project Administration, grade level and different objects and virtual learning environments, Wiki and Instrumentation and Control systems it was possible to identify, adapt, integrate and apply the B - Learning and Model PACIE as a strategy articulator of pedagogic practice in the use of TIC in a university technology program ${ }^{8}$.

It is recommended to incorporate aspects of Inclusion from disability and vulnerable populations through 
analysis of cases as well Systems Programs as technicians or technologists in systems, maintenance of computer equipment, Management Information Systems, Design and installation of Structured Cabling: For learners with visual disabilities it is necessary to have personal autonomy, the management of the tool jaws (for students and teachers), it should be noted that in topics such as databases through Microsoft Access to not work with Jaws, it is recommended to deepen with Microsoft Excel that if the supports. In the area of programming was not create difficulties since, this tool is best suited to their conditions is HTML by the greatest accessibility. In the component of preventive and predictive maintenance of hardware using their sense of touch and memory facilitates the learning process. Use the operating system Windows 7 Ultimate Lite version by Tecnoconocimiento accessible. To configure the BIOS and interpretation of plans for classes of networks requires support from a someone who does not present this disability. With regard to the learning of English the application Duolingo was the most effective way to contribute to the learning of vocabulary, pronunciation and writing?

In learners with hearing impairment does not need to be taught English, because their second language is sign language, and must have as a prerequisite the management of some form of communication not natural, such as lip reading or sign language facial Colombiana and count on personal autonomy, depending on its severity, may require a sign language interpreter Colombiana (LSC) that is who will transmit the knowledge imparted by the instructor. The issues related to the maintenance of hardware is easy, due to the ability of concentration that they develop. Unlike people with visual disabilities, can develop without inconvenience, and regardless the plan proposed curriculum, only it is important to note that must adapt the written material due to the limitation that present to understand the totality of the Spanish language, therefore, it is suggested its validation for the case of Manizales for the Association of the Deaf to which it is linked most of this population. In this sense, in Colombia deaf learners have been exempted from the study of foreign languages, in accordance with the provisions of the Decree 34 of
1980 of the Ministry of National Education, therefore, in the education proposals requiring as a condition of the handling of foreign languages such as English, French or another, must make a reflection and reach agreements about the level of demand to the deaf students, for whom the first language of them the Colombian Sign Language and the second Spanish. This does not mean that exclude definitely texts written in other languages, indispensable for the deepening of a theme; the deaf can seek strategies to gain access to the information present in these texts ${ }^{10}$.

The learning environments that use Institutes of Higher Education in the city of Manizales are: Blackboard (SENA) and Moodle (Autonomous University of Manizales, Universidad Antonio Nariño and Universidad de Caldas), in which the users have only access to them during the period in which the students, without options to return to them or be updated once approved or are discharged from the course. The purpose of this articulate the B-Learning and Model PACIE as elements of Educational Inclusion in Colombia through Information and Communication Technologies ICT from Web 2.0 developments made by the author in the higher education centres in the city of Manizales in which served as a teacher (Edublogs: Electrical Circuits, microcontrollers, Administration, Draft Grade, PLC), base of the research project on ICT use in the processes of formation, which is disclosed through articles published in scientific journals, papers at symposia, congresses or National and International Meetings ${ }^{11}$.

In this project used the VARK model is an acronym formed by the initial letters that refer to the four principles: (a) Visual sensory (visual): preference for graphic and symbolic ways to represent the information. b) (Auditory auditive): preference for listening to the information. c) Literacy (reading): preference for printed information in the form of words. d) Kinesthetic (kinesthetic): perceptual preference rationed with the use of the experience and practice, either real or simulated ${ }^{1,4,12}$.

\section{Conclusions}

It was noted that a common mistake of students is to start with coding, without making an analysis of the prob- 
lem, and the design prior to this step. The motivation is important when learning how to program, therefore you should start with simple exercises where the algorithmic process will focus the attention of the student. Develop an algorithm that allows adding two numbers; with this example we have the certainty that they understand the problem and to focus their efforts in the learning process that allows you to develop the algorithm to add two numbers. By applying what is described in this article resulted in a reduction of the percentage of students who lose the course of Introduction to Computing, from $44.12 \%$ in 2014-1 to $16.7 \%$ in 2017-1.

From the Resources Web 2.0 as Edublog Electrical Circuits, Edublog PLC, and the tools of online sessions of Blackboard Collaborate and instant messaging and Google Chrome of the Whatsapp messages are identified, adapt, integrate and apply the B - Learning and Model PACIE as a strategy articulator of the pedagogical practice of the teaching of Digital Logic and the logic of programming.

\section{References}

1. González Aldana M, Perdomo Osorio K, Pascuas Rengifo Y. Aplicación de las TIC en modelos educativos blendedlearning: Una revisión sistemática de literatura. Sophia. 2017; 13(1):144-54. https://doi.org/10.18634/sophiaj.13v.1i.364.

2. Flores Ferrer K, Bravo M. Metodología Pacie en los ambientes virtuales de aprendizaje para el logro de un aprendizaje colaborativo. Revista Electrónica Diálogos Educativos. 2017; 12(24):3-17.
3. Turpo Gebera O. Perspectiva de la convergencia pedagógica y tecnológica en la modalidad blendedlearning. Revista de educación a distancia. 2013; 39:1-14.

4. González A. La innovación educativa en educación superior: la modalidad blended learning. 018; Tesis para optar título de Especialista en Docencia en Entornos Virtuales, Universidad Nacional de Quilmes; Buenos Aires; 2018. p. $1-51$.

5. Bagnato M. La inclusión educativa en la ense-anza superior: retos y demandas. Educar em Revista; 2017. p.1526.

6. ChuldeMarcallaJ. Implementación y desarrollo de prácticas de automatización a través de un módulo didáctico con el PLC S7-1200 aplicados a sistemas de la agroindustria. Tesis para optar título de Ingeniero Electromecánico, Universidad de Cotopaxi extensión la Maná, Ecuador; 2017.

7. Comercio electrónico [Internet]. [cited 2016 Aug 12]. Available from: https://www.ipsos.com/es-pe/comercioelectronico-2016.

8. Cárdenas R. B-Learning en la formación del SENA. Rutas de formación: Prácticas y Experiencias. 2015; 1:44-51.

9. Toledo G. Accesibilidad digital para usuarios con limitaciones visuales. Tesis para optar título de Magister en Tecnología Informática Aplicada en Educación; Universidad Nacional de La Plata, Argentina; 2012.

10. Orozco C. Inclusión de personas en situación de discapacidad en el Centro de Automatización Industrial, Caldas. Rutas de formación: Prácticas y Experiencias. 2017; 9(4):82-7.

11. Cárdenas R, Prada H, Zú-iga E, Velásquez R, Ruíz L. B Learning en los proyectos de innovación y desarrollo tecnológico del semillero biometrónica del SENA regional Caldas. Caldas Colombia; 2015. p. 1-78.

12. Galvis Panqueva A. Procesos educativos apoyados con las herramientas digitales de la Piola. Informe técnico; 2015. p. $1-50$. 